\title{
Thiophene-forming one-pot synthesis of three thienyl-bridged oligophenothiazines and their electronic properties
}

\author{
Dominik Urselmann, Konstantin Deilhof, Bernhard Mayer and Thomas J. J. Müller
}

\author{
Full Research Paper \\ Address: \\ Institut für Organische Chemie und Makromolekulare Chemie, \\ Heinrich-Heine-Universität Düsseldorf, Universitätsstr. 1, D-40225 \\ Düsseldorf, Germany \\ Email: \\ Thomas J. J. Müller* - ThomasJJ.Mueller@uni-duesseldorf.de \\ * Corresponding author \\ Keywords: \\ C-C coupling; copper; cyclic voltammetry; DFT; microwave-assisted \\ synthesis; multicomponent reactions; palladium; phenothiazines; \\ thiophenes
}

Beilstein J. Org. Chem. 2016, 12, 2055-2064.

doi:10.3762/bjoc. 12.194

Received: 13 May 2016

Accepted: 11 August 2016

Published: 20 September 2016

This article is part of the Thematic Series "Organometallic chemistry".

Guest Editor: B. F. Straub

(c) 2016 Urselmann et al.; licensee Beilstein-Institut. License and terms: see end of document.

\begin{abstract}
The pseudo five-component Sonogashira-Glaser cyclization synthesis of symmetrically 2,5-diaryl-substituted thiophenes is excellently suited to access thienyl-bridged oligophenothiazines in a one-pot fashion. Three thienyl-bridged systems were intensively studied by UV-vis and fluorescence spectroscopy as well as by cyclic voltammetry. The oxidation proceeds with lower oxidation potentials and consistently reversible oxidations can be identified. The Stokes shifts are large and substantial fluorescence quantum yields can be measured. Computational chemistry indicates lowest energy conformers with sigmoidal and helical structure, similar to oligophenothiazines. TD-DFT and even semiempirical ZINDO calculations reproduce the trends of longest wavelengths absorption bands and allow the assignment of these transitions to possess largely charge-transfer character from the adjacent phenothiazinyl moieties to the central thienyl unit.
\end{abstract}

\section{Introduction}

Oligothiophenes [1-8] have adopted a dominating role among functional $\pi$-electron systems [9]. In particular, they have received attention as hole-transport materials in organic light emitting diodes [10-15], organic field-effect transistors [16-22], and organic photovoltaics [23-26]. Likewise their smaller congeners, 2,5-di(hetero)aryl substituted thiophenes [4,5], are equally relevant as charge-carrying materials $[2,3,27,28]$ and organic semiconductors $[29,30]$ in electronic [31] and optoelectronic devices [32-34]. As reversibly oxidizable units 2,5-

di(hetero)aryl-substituted thiophenes are additionally interesting as redox switchable molecular wires $[35,36]$ in unimolecular electronics [37-40].

In comparison to thiophene, phenothiazine, a tricyclic dibenzo1,4-thiazine, possesses a significantly lower oxidation potential, similar to aniline. However, phenothiazine derivatives form stable deeply colored radical cations with perfect Nernstian reversibility [41-44]. Over the past one and a half decades the 
synthetic and physical organic chemistry of oligophenothiazines have been intensively studied in linear [45] and cyclic [46] topologies, as diphenothiazinyl dumbbells brigded by heterocycles [47-49], and as acceptor [50,51], ferrocenyl [52], and alkynyl [53-55] substituted (oligo)phenothiazines. Their pronounced reversible oxidation potentials, their electro- and photochromicity [56], and their luminescence [57,58] have rendered (oligo)phenothiazines interesting candidates as donors in donor-acceptor conjugates with photo-induced electrontransfer characteristics [59-63], as hole-transport materials [64], for applications in mesoporous organo silica hybrid materials [65], and as chromophores in dye-sensitized solar cells [66-68] Furthermore, (oligo)phenothiazines in their native reduced forms display a pronounced ability to form self-assembled monolayers on gold [69-71] as well as on zinc and iron oxide surfaces [72].

Conceptually, thienyl-bridged oligophenothiazines can be considered as a novel type of structurally well-defined electronrich oligophenothiazine-thiophene hybrids (Figure 1). Thereby, the strong intramolecular electronic coupling of (oligo)phenothiazines $[45,64]$ and the low torsional displacement from a coplanar arrangement of both redox moieties of the dumbbells might represent conjugatively linked nanometer-scaled novel multistep redox active oligomers<smiles>[R]c1cc2c(cc1CC)N([R])c1cccc(c1)S2</smiles>

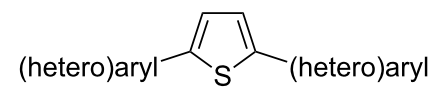

(oligo)phenothiazines 2,5-di(hetero)aryl-substituted thiophene
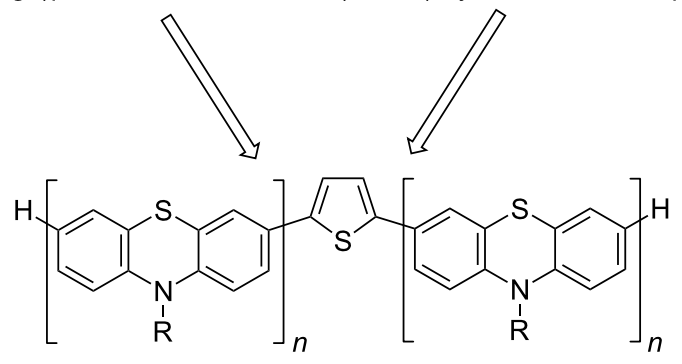

thienyl-bridged (oligo)phenothiazines

Figure 1: Thienyl-bridged oligophenothiazines as topological hybrids of (oligo)phenothiazines and 2,5-di(hetero)aryl substituted thiophene.

As part of our concept to develop novel multicomponent strategies for the synthesis of functional $\pi$-electron systems [73], we reasoned that our recently reported one-pot consecutive Sonogashira-Glaser sequence [74] and the resulting application to pseudo five-component syntheses of 2,5-di(hetero)arylthiophenes $[75,76]$ as well as intensively blue luminescent 2,5 - di(hetero)arylfurans [77] could open a highly convergent thiophene forming approach to the proposed title compounds. Here, we report the pseudo five-component synthesis of three thienylbridged oligophenothiazines by a one-pot Sonogashira-Glaser cyclization sequence and the electronic characterization by electronic spectroscopy, cyclic voltammetry, and quantum chemical computations.

\section{Results and Discussion Synthesis of thienyl-bridged oligophenothiazines}

Although the thienyl bridge can be introduced by Suzuki coupling as previously reported [48], we decided to transpose a methodology initiated by a Sonogashira-Glaser sequence [74] also for probing delicate oxidative dimerization conditions with easily oxidizable phenothiazinyl moieties. According to our recent study on the formation of butadiynyl-bridged diphenothiazines [54] we were optimistic to probe this unusual approach. First, three different bromo-substituted (oligo)phenothiazine substrates 1 had to be prepared. 3-Bromo-10-hexyl$10 H$-phenothiazine (1a) was synthesized according to the literature by hexylation of 3-bromo- $10 H$-phenothiazine [45]. The 7-bromo-substituted phenothiazines $\mathbf{1 b}$ and $\mathbf{1 c}$ were prepared in good yields according to our one-pot bromine-lithiumexchange-borylation-Suzuki (BLEBS) sequence [78], employing an excess of 3,7-dibromo-10-hexyl-10H-phenothiazine (3) [45] as a coupling component in the Suzuki step (Scheme 1).

With three bromo-substituted (oligo)phenothiazines $\mathbf{1}$ in hand the consecutive pseudo five-component Sonogashira-Glaser cyclization synthesis [75] was successfully performed furnishing three symmetrical thienyl-bridged oligophenothiazine dumbbells 3 as yellow greenish resins in yields of $34-54 \%$ (Scheme 2). The molecular composition of the thienyl-bridged oligophenothiazines $\mathbf{3}$ is unambiguously supported by mass spectrometry (MALDI-TOF). The proton and carbon NMR spectra unambiguously support the formation of the oligomers 3, and expectedly, in agreement with the molecular symmetry, the appearance of one (3a), two (3b), and three (3c) distinct resonances for the nitrogen-bound methylene carbon nuclei in the ${ }^{13} \mathrm{C}$ NMR spectra additionally supported the assigned structures. Combustion analyses of compounds $\mathbf{3 b}$ and $\mathbf{3 c}$ indicate that water and THF (compound $\mathbf{3 b}$ ) and water (compound $\mathbf{3 c}$ ) are present as solvent inclusion in the resins that cannot be removed even upon extensive drying under vacuo. However, HPLC traces with UV detection support that the materials consist of single specimen with over $99 \%$ purity. Taking into account that five new bonds are being formed in this consecutive pseudo five-component process the yield per bond forming step counts for $81-88 \%$, albeit a $\mathrm{Pd} / \mathrm{Cu}$ mediated air oxidation step is involved. 


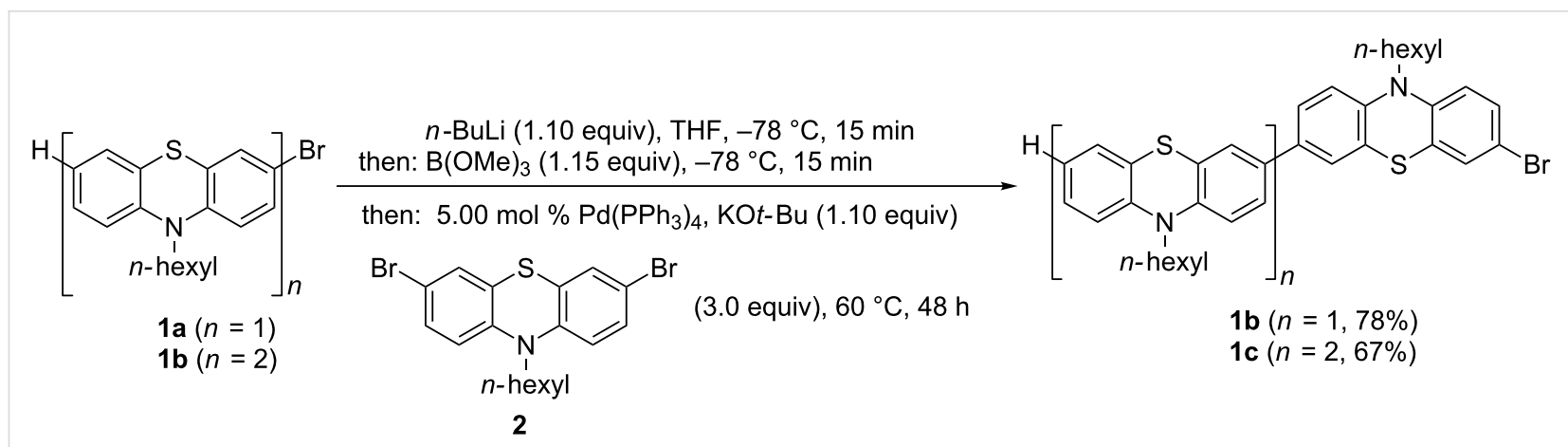

Scheme 1: One-pot bromine-lithium-exchange-borylation-Suzuki (BLEBS) synthesis of 7-bromo-substituted phenothiazines 1b and 1c with 3,7dibromo-10-hexyl-10H-phenothiazine (2).

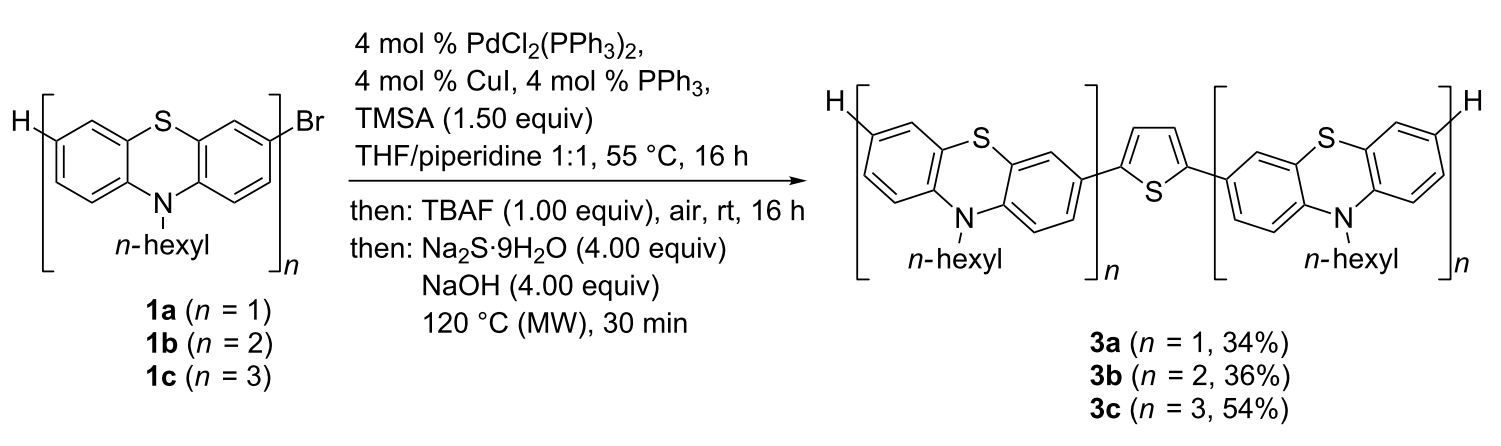

Scheme 2: Pseudo five-component Sonogashira-Glaser-cyclization synthesis of thienyl-bridged oligophenothiazine dumbbells 3.

\section{Electronic spectra and oxidation potentials}

The electronic properties of the three thienyl-bridged oligophenothiazines 3 were experimentally investigated by absorption and emission spectroscopy and by cyclic voltammetry (Table 1).

Cyclic voltammetry discloses the oxidation potential as an electronic ground state property. Therefore, the ease of oxidation of the title compounds 3 in comparison to the model 10-hexyl$10 \mathrm{H}$-phenothiazine with $E_{0}{ }^{0 /+1}=730 \mathrm{mV}$ was measured. All three thienyl-bridged oligophenothiazines 3 display cathodically shifted first oxidations in comparison to the model, however, with significantly more complex cyclovoltammetric signatures (Figure 2). The simplest representative, 2,5-bis(phenothiazinyl)thiophene 3a, possesses two reversible oxidation waves at $E_{1 / 2}=650$ and $760 \mathrm{mV}$ with Nernstian behavior (Figure 2, top),

Table 1: UV-vis and emission data and oxidation potentials of thienyl-bridged oligophenothiazines 3 (recorded in $\mathrm{CH}_{2} \mathrm{Cl}_{2}, T=298 \mathrm{~K}$; bold values: absorption and emission maxima used for determining the Stokes shift).

\begin{tabular}{|c|c|c|c|c|}
\hline compound & absorption $\lambda_{\max , a b s}(\varepsilon)[\mathrm{nm}]$ & emission $\lambda_{\max , e m}[\mathrm{~nm}]\left(\Phi_{\mathrm{f}}\right)[\%]^{\mathrm{a}}$ & Stokes shift ${ }^{\mathrm{b}} \Delta \tilde{\mathrm{v}}\left[\mathrm{cm}^{-1}\right]$ & $E_{1 / 2}[\mathrm{mV}]$ \\
\hline $3 a$ & $\begin{array}{l}246(39600), 261(39100), \\
318(27000), 395(33100)\end{array}$ & $506(18)$ & 5600 & 650,760 \\
\hline $3 b$ & $\begin{array}{l}266(52100), 284(45900) \\
319(32500), 404 \text { (27700) }\end{array}$ & $502(16)$ & 4800 & $\begin{array}{l}620-1010,,^{c} \\
1320-1520^{c, d}\end{array}$ \\
\hline $3 c$ & $\begin{array}{c}267(103000), 283(116200), \\
327(61000), 379(51900)\end{array}$ & $521(15)$ & 7200 & $550-950^{e}$ \\
\hline $\begin{array}{l}\text { 10-hexyl-10H- } \\
\text { phenothiazine }\end{array}$ & 258,312 & $444(-)$ & 9600 & 730 \\
\hline
\end{tabular}

a Recorded in $\mathrm{CH}_{2} \mathrm{Cl}_{2}$ at $c(3)=10^{-7} \mathrm{M}$ with coumarin 151 in ethanol/water $1: 1(\mathrm{w} / \mathrm{w})$ as a standard $\left(\Phi_{\mathrm{f}}=0.88\right) .{ }^{\mathrm{b}} \Delta \tilde{\mathrm{V}}=1 / \lambda_{\max , \text { abs }}-1 / \lambda_{\text {max,em }}\left[\mathrm{cm}{ }^{-1}\right]$; the UV-vis and emission data in bold face were applied for calculating the corresponding Stokes shifts. ${ }^{\mathrm{C}}$ Oxidation and reduction half-waves are not

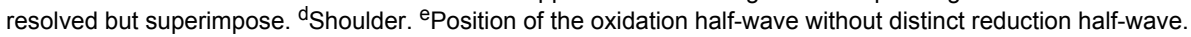




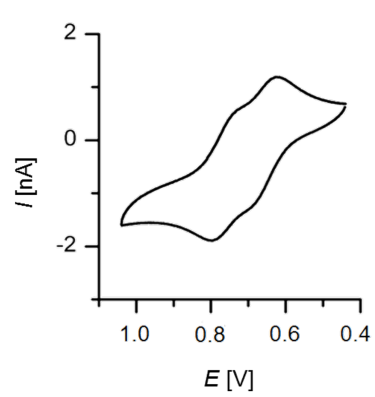

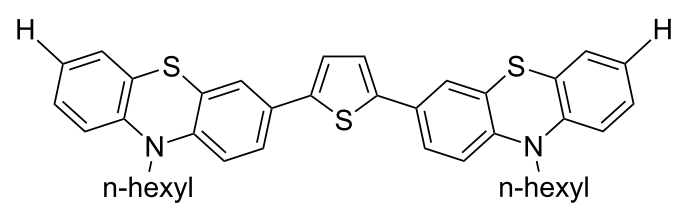
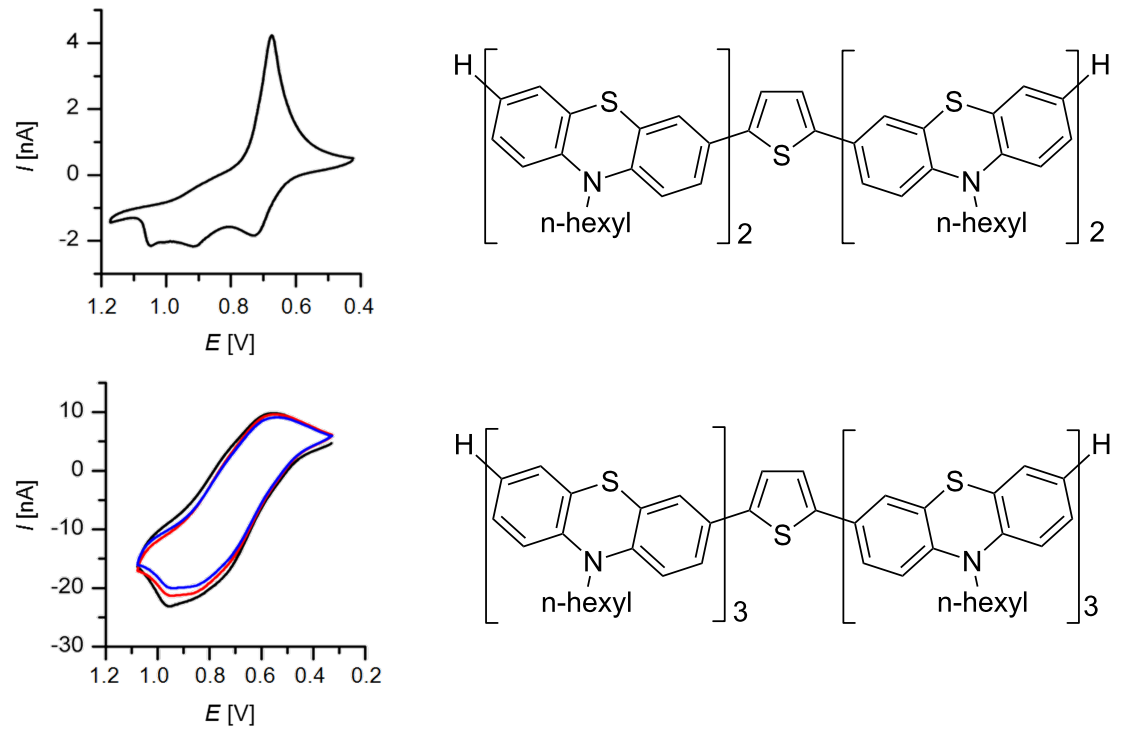

Figure 2: Cyclic voltammograms of compounds 3 (recorded in $\mathrm{CH}_{2} \mathrm{Cl}_{2}, T=293 \mathrm{~K}$, electrolyte $n$ - $\mathrm{Bu}_{4} \mathrm{~N}^{+} \mathrm{PF}{ }_{6}^{-}$, Pt working electrode, Pt counter electrode, $\mathrm{Ag} / \mathrm{AgCl}$ reference electrode, $v=50 \mathrm{mV} / \mathrm{s}$ (3a and $\mathbf{3 b}$ ), $v=100 \mathrm{mV} / \mathrm{s}$ (3c, multisweep experiment, 1. cycle (black), 2. cycle (red), 3. cycle (blue)).

indicating that the thiophene bridge enables electronic communication between both electrophore moieties. The first oxidation potential of 2,5-bis(diphenothiazinyl)thiophene $\mathbf{3 b}$ is cathodically shifted and appears at a peak potential of $E_{1 / 2}=620 \mathrm{mV}$, however, without displaying Nernstian behavior (Figure 2, center). Two further oxidation waves can be detected; yet, the corresponding reduction half-waves are absent. Only an increased reduction half wave indicates the presence of multiply oxidized specimens that are reduced at the same potential as a consequence of electrode deposition. For the 2,5-bis(triphenothiazinyl)thiophene $3 \mathbf{c}$ no distinct reversible oxidation waves can be identified but rather a continuous oxidation window ranging from 500 to $1000 \mathrm{mV}$ (Figure 2, bottom). Yet, the multisweep experiment indicates that within this window oxidation and reduction occurs in a reversible fashion.

However, the cyclic voltammograms of this system containing six phenothiazines conjugatively linked via a symmetrically substituted thiophene bridge do not obey a strictly Nernstian behavior. Thereby, a first oxidation potential of $E_{1 / 2}=550 \mathrm{mV}$ was estimated. Interestingly, by carefully selecting the applied reversal voltage thienyl-bridged oligophenothiazines $\mathbf{3}$ can be reversible charged and discharged, a property that is highly desired for molecular electronics applications.

The absorption spectra undoubtedly follow the Lambert-Beer law in a broad concentration range (as studied for compounds 3b and 3c, see Supporting Information File 1, Figures S3 and S4). In addition this behavior underlines that no aggregation of the molecules has to be taken into account at the concentration level of absorption and emission spectroscopy. In the UV-vis spectra, most characteristically, four absorption bands are found, three at shorter wavelengths arising from the phenothiazinyl moieties and the longest wavelength maximum can be assigned to the central 2,5-di(hetero)aryl-substituted thiophene part (Figure 3). This assignment is based on the molar decadic extinction coefficients that increase with the number of phenothiazinyl units (Table 1). However, the increasing number of phenothiazinyl moieties enhances the donor character of the substituents on the thiophene core. In turn the thienyl moiety behaves as an acceptor due to its higher oxidation potential. Interestingly, the redshift of the longest wavelength absorption 


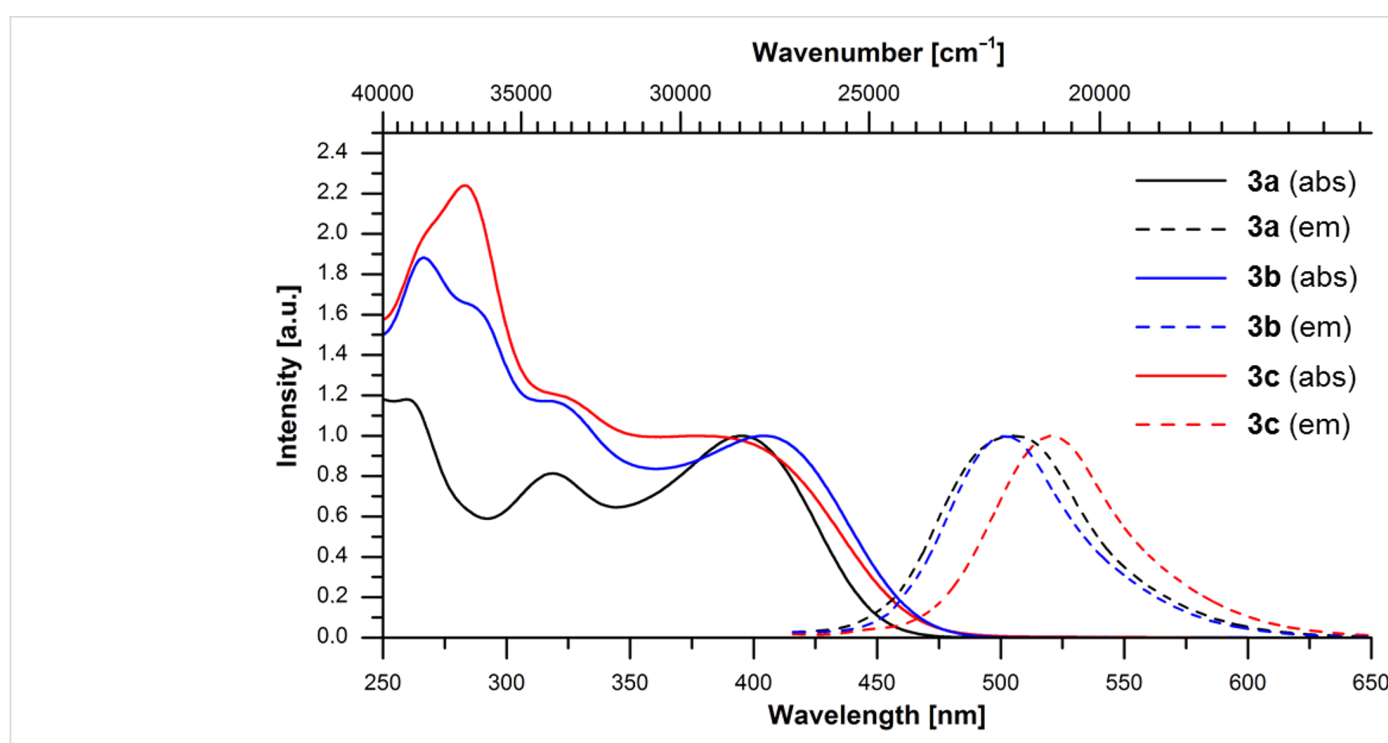

Figure 3: UV-vis (solid lines) and fluorescence spectra (dashed lines) of the thienyl-bridged oligophenothiazines $3\left(\right.$ recorded in $\mathrm{CH}_{2} \mathrm{Cl}_{2}, T=298 \mathrm{~K}$ )

band is relatively moderate, presumably as a consequence of only a modest delocalization of the complete $\pi$-electron systems in the electronic ground state.

In the emission spectra broad shortest wavelength bands appear in a region from 502 to $521 \mathrm{~nm}$ with large Stokes shifts $\Delta \tilde{v}$ between 4800 and $7200 \mathrm{~nm}$ (Figure 2), which are typical for oligophenothiazines [45]. However, the lack of a systematic trend with the numbers of phenothiazinyl units indicates that the excited state property is strongly affected by local conformational biases arising from the planarization of electronic ground state butterfly conformation of phenothiazines in the excited state $[57,79]$. Also the fluorescence quantum yields $\Phi_{\mathrm{f}}$ with 15 to $18 \%$ essentially remain constant within this series, although, the increasing number of sulfur-containing heterocycles suggests an increase in fluorescence deactivating spin-orbit coupling. In comparison to the consanguineous oligophenothiazines [45] the compounds 3 display considerable lower fluorescence quantum yields.

\section{Computations and electronic structure}

The electronic properties of the three thienyl-bridged oligophenothiazines 3 were further investigated by computational studies on the DFT level of theory. First the ground state geometries of structures $\mathbf{3 a}, \mathbf{3} \mathbf{b}$, and $\mathbf{3 c}$ (the $n$-hexyl substituents were truncated to ethyl groups for reducing the computational time) were optimized by DFT calculations with the B3LYP functional and the $6-311 \mathrm{G}(\mathrm{d}, \mathrm{p})$ basis set as implemented in the program package Gaussian 09 [80]. In addition the minima structures were confirmed by the absence of imaginary vibrations in the analytical frequency analyses. The inspection of the computed molecular structures 3 indicates that these molecules adopt sigmoidal and helical minimum conformers (Figure 4) as already shown for consanguineous series of higher oligophenothiazines [45].

With these geometry-optimized structures in hand the electronic absorptions were calculated with the semiempirical ZINDO-CI, and TD-DFT (B3LYP and CAM-B3LYP, an implemented hybrid exchange-correlation functional [81], using the polarizable continuum model (PCM) [82] applying dichloromethane as solvent) methods and the results were compared with the experimentally obtained UV-vis absorption spectra (see Supporting Information File 1, Table S2) and the calculated energies of the FMOs (frontier molecular orbitals) (see Supporting Information File 1, Table S3).

Although a perfect numerical match of experimentally and computationally determined absorption bands cannot be expected for conformationally flexible complex molecules with extended $\pi$-conjugation, the trend of the longest wavelength absorption bands from the UV-vis spectra is correctly reproduced. Furthermore, for all three methods and for all three structures this longest wavelength absorption can be assigned to $\mathrm{S}_{1}$ states that predominantly consist of HOMO to LUMO transitions with dominant oscillator strengths. For the thienyl-bridged 2,5-bis(terphenothiazinyl)thiophene $\mathbf{3 c}$, containing the symmetrical conjugative ligation of two terphenothiazinyl moieties to the thienyl bridge, in the TD-DFT methods significant contributions of HOMO-2 to LUMO transitions contribute to the corresponding $\mathrm{S}_{1}$ states. The inspection of the Kohn-Sham FMOs, contributing to the $S_{1}$ states and representing the longest wavelength absorption bands, indicates that the nature of these transitions possesses predominantly a charge-transfer character from 


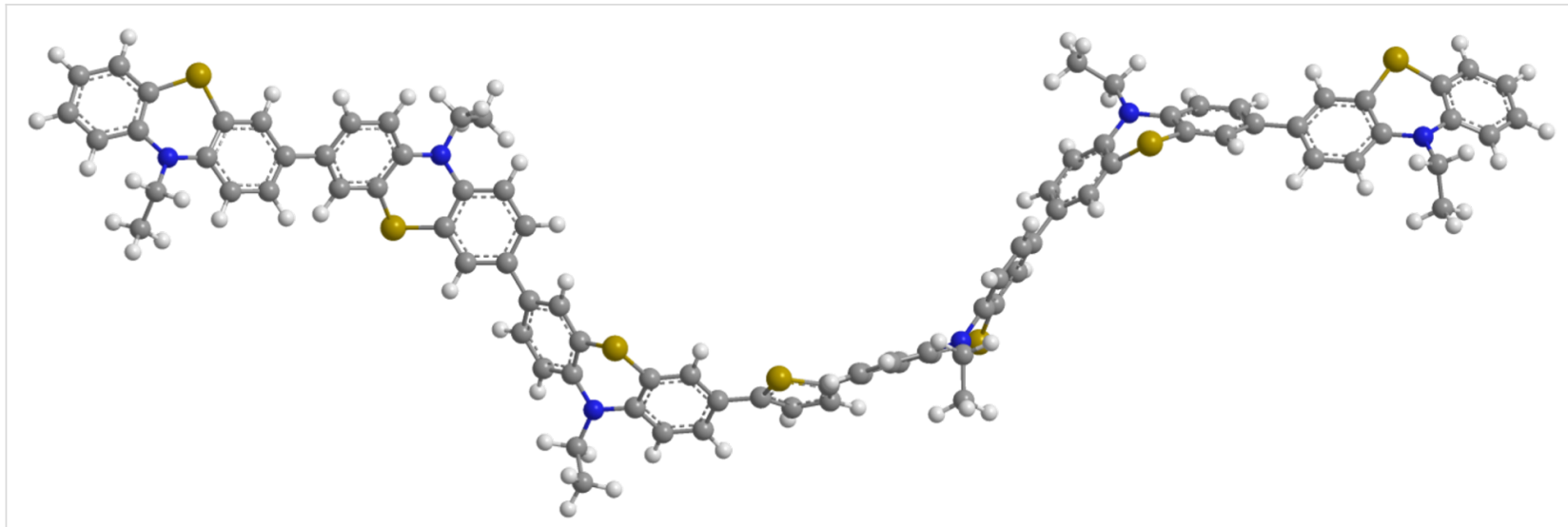

Figure 4: DFT-calculated minimum conformer of the 2,5-bis(terphenothiazinyl)thiophene 3c (calculated with the B3LYP functional and the $6-311 \mathrm{G}(\mathrm{d}, \mathrm{p})$ basis set).

the adjacent phenothiazinyl moieties to the central thiophene part. The intense coefficient density in the center of the structures in both HOMO (HOMO-2) and LUMO additionally supports and rationalizes the dominant magnitude of the oscillator strengths $f$, corresponding with significant decadic molar extinction coefficients of the associated bands (Figure 5). In principle these phenothiazine conjugates can be considered as donor-acceptor-donor systems, a topology that can be favorably developed further in molecular electronics.

\section{Conclusion}

In summary, we could show that the pseudo five-component Sonogashira-Glaser cyclization synthesis of symmetrically 2,5 diaryl-substituted thiophenes can be efficiently transposed to

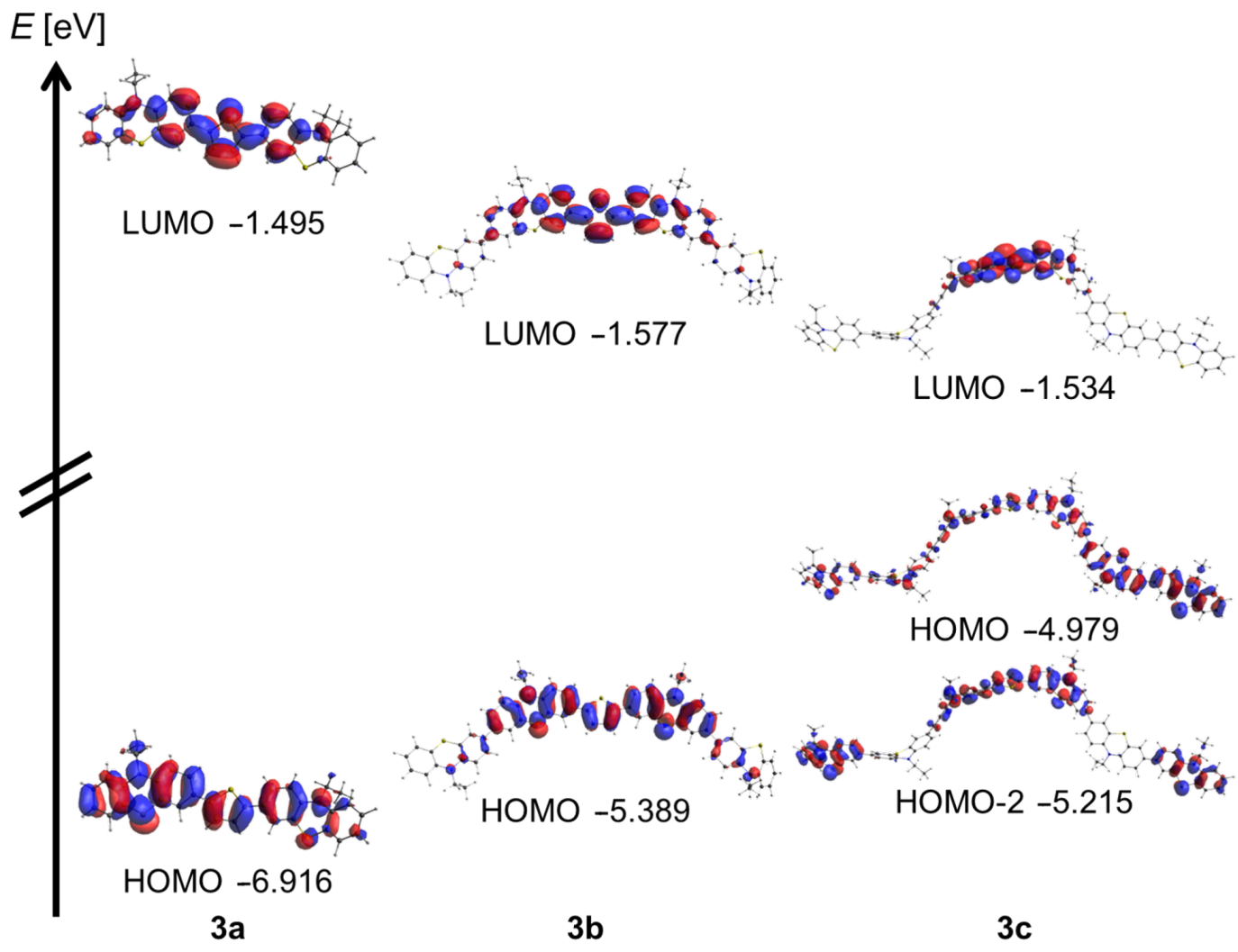

Figure 5: Relevant Kohn-Sham FMOs contributing to the $S_{1}$ states that are assigned to the longest wavelengths absorption bands of thienyl-bridged oligophenothiazines 3 (calculated with the B3LYP functional in vacuo and the $6-311 \mathrm{G}(\mathrm{d}, \mathrm{p})$ basis set). 
access thienyl-bridged oligophenothiazines in a one-pot fashion starting from 3-bromo(oligo)phenothiazines. Most remarkably, the oxidative conditions of the central Glaser step employing air as oxidant does not interfere with the oxidation sensitive (oligo)phenothiazinyl moieties. The electronic properties of the obtained three thienyl-bridged systems were intensively studied by UV-vis and fluorescence spectroscopy as well as by cyclic voltammetry. With increasing numbers of phenothiazinyl electrophore units the oxidation proceeds with lower oxidation potentials and for the 2,5-bis(terphenothiazinyl)thiophene even a consistently reversible oxidation area can be found. As already shown for oligophenothiazines and typical for many 3-(hetero)arylphenothiazines the Stokes shifts are large and substantial fluorescence quantum yields can be measured. Computational chemistry supports lowest-energy conformers with sigmoidal and helical structure, similar to oligophenothiazines. Furthermore, TD-DFT and even semiempirical ZINDO calculations on geometry-optimized simplified structures of the title compounds nicely reproduce the trends of longest wavelength absorption bands and allow the assignment of these transitions to be largely charge-transfer from the adjacent phenothiazinyl moieties to the central thienyl unit. This represents in principle a donor-acceptor-donor topology, suitable for further development toward molecular electronics. Studies employing the presented synthetic methodology and the concept of bridging oligophenothiazines with conjugating bridges of variable electronic nature are currently underway.

\section{Experimental}

3a (general procedure GP): 3-Bromo-10-hexyl-10H-phenothiazine (1a) (725 mg, $2.00 \mathrm{mmol})$ and dry THF (10.0 mL) were placed in a microwave vessel with septum $(80 \mathrm{~mL})$ and the mixture was deaerated by a constant stream of nitrogen through a syringe for $10 \mathrm{~min}$. Then $\mathrm{PdCl}_{2}\left(\mathrm{PPh}_{3}\right)_{2}(56.0 \mathrm{mg}, 0.08 \mathrm{mmol})$, $\mathrm{CuI}$ (15.0 mg, $0.08 \mathrm{mmol}), \mathrm{PPh}_{3}(21 \mathrm{mg}, 0.08 \mathrm{mmol})$, (trimethylsilyl)acetylene $(0.56 \mathrm{~mL}, 2.00 \mathrm{mmol})$, and piperidine $(5.00 \mathrm{~mL}, 50.4 \mathrm{mmol})$ were added. The closed vessel under nitrogen was heated at $55{ }^{\circ} \mathrm{C}$ (oil bath) for $16 \mathrm{~h}$. Next, TBAF $3 \mathrm{H}_{2} \mathrm{O}(631 \mathrm{mg}, 2.00 \mathrm{mmol})$ was added and the vessel open to ambient atmosphere was then stirred at room temp for $16 \mathrm{~h}$. Then, sodium sulfide nonahydrate $(960 \mathrm{mg}, 4.00 \mathrm{mmol})$ and potassium hydroxide ( $224 \mathrm{mg}, 4.00 \mathrm{mmol}$ ) were added and the reaction mixture in the closed vessel was heated at $120^{\circ} \mathrm{C}$ in the microwave cavity for $30 \mathrm{~min}$. After cooling to room temperature the solvents were removed in vacuo and the residue was filtered with THF through a short plug of Celite ${ }^{\circledR}$ and silica gel. The solvents were removed in vacuo and the residue was purified by chromatography on silica gel (hexane/dichlormethane 10:1) giving $218 \mathrm{mg}$ (34\%) of compound 3a as a yellow greenish resin. $R_{\mathrm{f}} 0.53$ (hexane/acetone 10:1); ${ }^{1} \mathrm{H}$ NMR (300 $\mathrm{MHz}$, acetone- $\left.d_{6}\right) \delta 0.84\left(\mathrm{t},{ }^{3} J=7.1 \mathrm{~Hz}, 6 \mathrm{H}\right), 1.21-1.33(\mathrm{~m}$,
$8 \mathrm{H}), 1.39-1.51(\mathrm{~m}, 4 \mathrm{H}), 1.78$ (quint, $\left.{ }^{3} J=7.5 \mathrm{~Hz}, 4 \mathrm{H}\right), 3.92(\mathrm{t}$, $\left.{ }^{3} J=7.0 \mathrm{~Hz}, 4 \mathrm{H}\right), 6.90-6.97(\mathrm{~m}, 2 \mathrm{H}), 6.97-7.03(\mathrm{~m}, 4 \mathrm{H}), 7.14$ $\left(\mathrm{dd},{ }^{3} J=7.7 \mathrm{~Hz},{ }^{4} J=1.5 \mathrm{~Hz}, 2 \mathrm{H}\right), 7.16-7.23(\mathrm{~m}, 2 \mathrm{H}), 7.29$ (s, 2H), $7.41\left(\mathrm{~d},{ }^{4} J=2.1 \mathrm{~Hz}, 2 \mathrm{H}\right), 7.44\left(\mathrm{dd},{ }^{3} J=8.4 \mathrm{~Hz},{ }^{4} J=2.2\right.$ $\mathrm{Hz}, 2 \mathrm{H}) ;{ }^{13} \mathrm{C}$ NMR $\left(75 \mathrm{MHz}\right.$, acetone- $\left.d_{6}\right) \delta 14.3\left(2 \mathrm{CH}_{3}\right), 23.3$ $\left(2 \mathrm{CH}_{2}\right), 27.1\left(2 \mathrm{CH}_{2}\right), 27.5\left(2 \mathrm{CH}_{2}\right), 32.2\left(2 \mathrm{CH}_{2}\right), 47.9\left(2 \mathrm{CH}_{2}\right)$, $116.7(2 \mathrm{CH}), 116.8(2 \mathrm{CH}), 123.4(2 \mathrm{CH}), 124.5(2 \mathrm{CH}), 124.5$ $(2 \mathrm{CH}), 124.8\left(2 \mathrm{C}_{\text {quat }}\right), 125.4(2 \mathrm{CH}), 126.1\left(2 \mathrm{C}_{\text {quat }}\right), 128.1$ $(2 \mathrm{CH}), 128.4(2 \mathrm{CH}), 129.6\left(2 \mathrm{C}_{\text {quat }}\right), 142.5\left(2 \mathrm{C}_{\text {quat }}\right), 145.5$ $\left(2 \mathrm{C}_{\text {quat }}\right), 145.8\left(2 \mathrm{C}_{\text {quat }}\right)$; MS (MALDI) $\mathrm{m} / \mathrm{z}: 646.3\left([\mathrm{M}]^{+}\right)$; UV-vis $\left(\mathrm{CH}_{2} \mathrm{Cl}_{2}\right), \lambda_{\max }[\mathrm{nm}](\varepsilon): 246$ (39600), 261 (39100), 318 (27000), 395 (33100); IR (KBr) $\tilde{v}\left[\mathrm{~cm}^{-1}\right]: 3057(\mathrm{w}), 2951$ (w), $2926(w), 2851(w), 1917(w), 1597(w), 1576(w), 1539$ (w), $1489(\mathrm{w}), 1458(\mathrm{~s}), 1398(\mathrm{w}), 1362(\mathrm{w}), 1331(\mathrm{~m}), 1285$ (w), $1248(\mathrm{~m}), 1238(\mathrm{~m}), 1225(\mathrm{w}), 1192(\mathrm{w}), 1161(\mathrm{w}), 1134$ (w), $1103(w), 1038(w), 1022(w), 968(w), 926(w), 908(w)$, $874(\mathrm{w}), 793(\mathrm{~s}), 745(\mathrm{~s}), 704(\mathrm{w}), 681(\mathrm{w}), 669(\mathrm{w}), 646(\mathrm{w})$, 625 (w); anal. calcd for $\mathrm{C}_{40} \mathrm{H}_{42} \mathrm{~N}_{2} \mathrm{~S}_{3}$ (647.0): C, 74.26; H, 6.54; N, 4.33; found: C, 74.17; H, 6.79; N, 4.05 .

3b: According to the GP by reaction of 7-bromo-10,10'-dihexyl$10 H, 10 ' H$-3,3'-biphenothiazine (1b, $1.29 \mathrm{~g}, 2.00 \mathrm{mmol})$ after chromatography on silica gel (hexane/THF 20:1) gave $435 \mathrm{mg}$ (36\%) of compound $\mathbf{3 b}$ as a yellow greenish resin. ${ }^{1} \mathrm{H}$ NMR $\left(600 \mathrm{MHz}, \mathrm{CDCl}_{3}\right) \delta 0.65-0.82(\mathrm{~m}, 12 \mathrm{H}), 1.10-1.23(\mathrm{~m}, 16 \mathrm{H})$, $1.26-1.36(\mathrm{~m}, 8 \mathrm{H}), 1.62-1.76(\mathrm{~m}, 8 \mathrm{H}), 3.62-3.79(\mathrm{~m}, 8 \mathrm{H})$, 6.64-6.84 (m, 10H), 6.93-7.09 (m, 6H), 7.09-7.26 (m, 12H); ${ }^{13} \mathrm{C}$ NMR $\left(151 \mathrm{MHz}, \mathrm{CDCl}_{3}\right) \delta 14.1\left(\mathrm{CH}_{3}\right), 22.7\left(\mathrm{CH}_{2}\right), 26.7$ $\left(\mathrm{CH}_{2}\right), 26.7\left(\mathrm{CH}_{2}\right), 26.8\left(\mathrm{CH}_{2}\right), 26.9\left(\mathrm{CH}_{2}\right), 31.5\left(\mathrm{CH}_{2}\right), 47.5$ $\left(\mathrm{CH}_{2}\right), 47.6\left(\mathrm{CH}_{2}\right), 115.3(\mathrm{CH}), 115.4(\mathrm{CH}), 115.5(\mathrm{CH}), 115.5$ $(\mathrm{CH}), 122.4(\mathrm{CH}), 123.1(\mathrm{CH}), 124.2(\mathrm{CH}), 124.4\left(\mathrm{C}_{\text {quat }}\right), 124.4$ $\left(\mathrm{C}_{\text {quat }}\right), 124.6(\mathrm{CH}), 124.8\left(\mathrm{C}_{\text {quat }}\right), 125.1(\mathrm{CH}), 125.1(\mathrm{CH})$, $125.2(\mathrm{CH}), 125.3(\mathrm{CH}), 127.3(\mathrm{CH}), 127.5(\mathrm{CH}), 128.9\left(\mathrm{C}_{\text {quat }}\right)$, $134.2\left(\mathrm{C}_{\text {quat }}\right), 134.4\left(\mathrm{C}_{\text {quat }}\right), 141.9\left(\mathrm{C}_{\text {quat }}\right), 143.7$ ( $\left.\mathrm{C}_{\text {quat }}\right), 144.2$ ( $\left.\mathrm{C}_{\text {quat }}\right), 144.3\left(\mathrm{C}_{\text {quat }}\right), 145.1\left(\mathrm{C}_{\text {quat }}\right)$; MS (MALDI) $\mathrm{m} / \mathrm{z}: 1208.5$ $\left([\mathrm{M}]^{+}\right) ; \mathrm{UV}-$ vis $\left(\mathrm{CH}_{2} \mathrm{Cl}_{2}\right), \lambda_{\max }[\mathrm{nm}](\varepsilon): 266$ (52100), 284 (45900), 319 (32500), 404 (27700); IR (KBr) $\tilde{v}\left[\mathrm{~cm}^{-1}\right]: 2951$ (w), $2922(\mathrm{w}), 2853(\mathrm{w}), 1456(\mathrm{~s}), 1416(\mathrm{w}), 1375(\mathrm{w}), 1364$ (w), $1331(\mathrm{~m}), 1292(\mathrm{w}), 1238(\mathrm{~m}), 1192(\mathrm{w}), 1138(\mathrm{w}), 1105$ (w), 1063 (w), 1040 (w), 872 (m), 797 (s), 745 (s), 727 (w), 706 (w), $611(\mathrm{w})$; anal. calcd for $\mathrm{C}_{76} \mathrm{H}_{80} \mathrm{~N}_{4} \mathrm{~S}_{5} \cdot \mathrm{H}_{2} \mathrm{O} \cdot 2 \mathrm{C}_{4} \mathrm{H}_{8} \mathrm{O}(1209.8$ + 18.0 + 144.2): C, 73.53; H, 7.20; N, 4.08; found: C, 73.39; H, 7.36; N, 4.29; HPLC ( $n$-hexane) $t_{\mathrm{R}}[\mathrm{min}](\%)=4.49(99)$.

3c: According to the GP by reaction of 7-bromo-10,10',10', trihexyl-10H,10' $H, 10$ ' ' $H$-[3,3', 7',3', ]terphenothiazin (1c, $1.85 \mathrm{~g}, 2.00 \mathrm{mmol}$ ) after chromatography on silica gel (hexane/ THF 7:1 to $3: 1)$ gave $955 \mathrm{mg}(54 \%)$ of compound $\mathbf{3 c}$ as a yellow greenish resin. ${ }^{1} \mathrm{H} \mathrm{NMR}\left(600 \mathrm{MHz}, \mathrm{CDCl}_{3}\right) \delta 0.75-0.88$ (m, 18H), 1.08-1.33 (m, 24H), 1.31-1.40 (m, 12H), 1.66-1.81 (m, 12H), 3.60-3.89 (m, 12H), 6.68-6.88 (m, 14H), 7.00-7.11 
(m, 6H), 7.13-7.37 (m, 20H); $\left.{ }^{13} \mathrm{C} \mathrm{NMR} \mathrm{(151} \mathrm{MHz,} \mathrm{CDCl}_{3}\right) \delta$ $14.05\left(\mathrm{CH}_{3}\right), 14.06\left(\mathrm{CH}_{3}\right), 22.64\left(\mathrm{CH}_{2}\right), 22.66\left(\mathrm{CH}_{2}\right), 26.69$ $\left(\mathrm{CH}_{2}\right), 26.72\left(\mathrm{CH}_{2}\right), 26.8\left(\mathrm{CH}_{2}\right), 26.88\left(\mathrm{CH}_{2}\right), 26.90\left(\mathrm{CH}_{2}\right)$, $31.5\left(\mathrm{CH}_{2}\right), 47.5\left(\mathrm{CH}_{2}\right), 47.6\left(\mathrm{CH}_{2}\right), 47.63\left(\mathrm{CH}_{2}\right), 115.31(\mathrm{CH})$, $115.37(\mathrm{CH}), 115.42(\mathrm{CH}), 115.46(\mathrm{CH}), 115.48(\mathrm{CH}), 122.3$ $(\mathrm{CH}), 123.1(\mathrm{CH}), 124.2(\mathrm{CH}), 124.42\left(\mathrm{C}_{\text {quat }}\right), 124.44\left(\mathrm{C}_{\text {quat }}\right)$, $124.57(\mathrm{CH}), 124.68\left(\mathrm{C}_{\text {quat }}\right), 124.72\left(\mathrm{C}_{\text {quat }}\right), 124.8(\mathrm{CH})$, $125.12(\mathrm{CH}), 125.14(\mathrm{CH}), 125.18(\mathrm{CH}), 125.19(\mathrm{CH}), 125.25$ $(\mathrm{CH}), 125.29(\mathrm{CH}), 127.25(\mathrm{CH}), 127.5(\mathrm{CH}), 128.9\left(\mathrm{C}_{\text {quat }}\right)$, $134.18\left(\mathrm{C}_{\text {quat }}\right), 134.23\left(\mathrm{C}_{\text {quat }}\right), 134.30\left(\mathrm{C}_{\text {quat }}\right), 134.37\left(\mathrm{C}_{\text {quat }}\right)$, $141.9\left(\mathrm{C}_{\text {quat }}\right), 143.7\left(\mathrm{C}_{\text {quat }}\right), 143.9\left(\mathrm{C}_{\text {quat }}\right), 144.0\left(\mathrm{C}_{\text {quat }}\right), 144.20$ $\left(\mathrm{C}_{\text {quat }}\right), 144.22\left(\mathrm{C}_{\text {quat }}\right), 145.1\left(\mathrm{C}_{\text {quat }}\right)$; MS (MALDI) m/z: 1770.7 $\left([\mathrm{M}]^{+}\right) ; \mathrm{UV}-$ vis $\left(\mathrm{CH}_{2} \mathrm{Cl}_{2}\right), \lambda_{\max }[\mathrm{nm}](\varepsilon): 267$ (103000), 283 (116200), 327 (61000), 379 (51900); IR (KBr) $\tilde{v}\left[\mathrm{~cm}^{-1}\right]: 3024$ (w), $2951(w), 2922(w), 2851(w), 1603(w), 1574(w), 1454$ (s), $1416(\mathrm{w}), 1377$ (w), 1331 (w), 1294 (w), 1238 (m), 1190 (w), $1140(\mathrm{w}), 1105(\mathrm{w}), 1063(\mathrm{w}), 1038(\mathrm{w}), 968(\mathrm{w}), 928(\mathrm{w})$, $910(\mathrm{w}), 872$ (w), 802 (s), 745 (m), 729 (w), 691 (w); anal. calcd for $\mathrm{C}_{112} \mathrm{H}_{118} \mathrm{~N}_{6} \mathrm{~S}_{7} \cdot \mathrm{H}_{2} \mathrm{O}(1772.63+18.0)$ : C, 75.13; H, 6.76; N, 4.69; found: C, 74.89; H, 6.50; N, 4.53; HPLC $\left(n\right.$-hexane/THF 99.5:0.5) $t_{R}[\mathrm{~min}](\%)=2.92(99)$.

\section{Supporting Information}

The Supporting Information contains all experimental procedures, spectroscopic and analytical data of compounds $\mathbf{3}$, and copies of NMR spectra of compounds 3 , copies of the HPLC-traces of compounds $\mathbf{3 b}$ and $\mathbf{3} \mathbf{c}$, Lambert-Beer plots of compounds $\mathbf{3 b}$ and $\mathbf{3 c}$, computed xyz-coordinates of the thienyl-bridged oligophenothiazines $\mathbf{3 a}, \mathbf{3 b}$, and $\mathbf{3 c}$, computed UV-vis spectra of ZINDO-CI and TD-DFT (B3LYP, CAM-B3LYP) calculated structures of $\mathbf{3 a}, \mathbf{3 b}$, and $3 \mathbf{c}$, computed FMOs (frontier molecular orbitals) of the calculated structures $\mathbf{3 a}, \mathbf{3 b}$, and $\mathbf{3 c}$.

\section{Supporting Information File 1}

Experimental and analytical data.

[http://www.beilstein-journals.org/bjoc/content/ supplementary/1860-5397-12-194-S1.pdf]

\section{Acknowledgements}

The authors cordially thank the Fonds der Chemischen Industrie and the Deutsche Forschungsgemeinschaft (Mu 1088/9-1) for financial support.

\section{References}

1. Otero, R.; Gallego, J. M.; Vázquez de Parga, A. L.; Martín, N.; Miranda, R. Adv. Mater. 2011, 23, 5148-5176. doi:10.1002/adma.201102022
2. Zhao, X.; Zhan, X. Chem. Soc. Rev. 2011, 40, 3728-3743. doi:10.1039/C0CS00194E

3. Shirota, Y.; Kageyama, H. Chem. Rev. 2007, 107, 953-1010. doi:10.1021/cr050143+

4. Barbarella, G.; Melucci, M.; Sotgiu, G. Adv. Mater. 2005, 17, 1581-1593. doi:10.1002/adma.200402020

5. Mishra, A.; Ma, C.-Q.; Bäuerle, P. Chem. Rev. 2009, 109, 1141-1276. doi:10.1021/cr8004229

6. Handbook of Oligo- and Polythiophenes; Fichou, D., Ed.; Wiley-VCH GmbH \& Co. KGaA: Weinheim, Germany, 1999. doi:10.1002/9783527611713

7. Müllen, K.; Klärner, G. In Electronic Materials: The Oligomer Approach; Müllen, K.; Wegner, G., Eds.; Wiley-VCH Verlag GmbH \& Co. KGaA: Weinheim, Germany, 1998.

8. Hotta, S. Chapter 8. In Handbook of Organic conducting Molecules and Polymers; Nalwa, H. S., Ed.; Wiley: Chichester, United Kingdom, 1997; Vol. 2.

9. Müller, T. J. J.; Bunz, U. H. F., Eds. Functional Organic Materials. Syntheses, Strategies, and Applications; Wiley-VCH Verlag $\mathrm{GmbH}$ \& Co. KGaA: Weinheim, Germany, 2007. doi:10.1002/9783527610266

10. Yook, K. S.; Lee, J. Y. Adv. Mater. 2012, 24, 3169-3190. doi:10.1002/adma.201200627

11. Zhong, C.; Duan, C.; Huang, F.; Wu, H.; Cao, Y. Chem. Mater. 2011, 23, 326-340. doi:10.1021/cm101937p

12. Geiger, F.; Stoldt, M.; Schweizer, H.; Bäuerle, P.; Umbach, E. Adv. Mater. 1993, 5, 922-925. doi:10.1002/adma.19930051210

13. Fichou, D. J. Mater. Chem. 2000, 10, 571-588. doi:10.1039/A908312J

14. Mitschke, U.; Bäuerle, P. J. Mater. Chem. 2000, 10, 1471-1507. doi:10.1039/A908713C

15. Perepichka, I. F.; Perepichka, D. F.; Meng, H.; Wudl, F. Adv. Mater. 2005, 17, 2281-2305. doi:10.1002/adma.200500461

16. Wang, C.; Dong, H.; Hu, W.; Liu, Y.; Zhu, D. Chem. Rev. 2012, 112, 2208-2267. doi:10.1021/cr100380z

17. Horowitz, G.; Fichou, D.; Peng, X.; Xu, Z.; Garnier, F. Solid State Commun. 1989, 72, 381-384. doi:10.1016/0038-1098(89)90121-X

18. Garnier, F.; Horowitz, G.; Peng, X.; Fichou, D. Adv. Mater. 1990, 2 , 592-594. doi:10.1002/adma.19900021207

19. Garnier, F.; Hajlaoui, R.; Yassar, A.; Srivastava, P. Science 1994, 265 , 1684-1686. doi:10.1126/science.265.5179.1684

20. Sirringhaus, H.; Kawase, T.; Fried, R. H.; Shimoda, T.; Inbasekaran, M.; Wu, W.; Woo, E. P. Science 2000, 290, 2123-2126. doi:10.1126/science.290.5499.2123

21. Ong, B. S.; Wu, Y.; Liu, P.; Gardner, S. J. Am. Chem. Soc. 2004, 126, 3378-3379. doi:10.1021/ja039772w

22. Waldauf, C.; Schilinsky, P.; Perisutti, M.; Hauch, J.; Brabec, C. J. Adv. Mater. 2003, 15, 2084-2088. doi:10.1002/adma.200305623

23. Son, H. J.; He, F.; Carsten, B.; Yu, L. J. Mater. Chem. 2011, 21 , 18934-18945. doi:10.1039/C1JM12388B

24. Facchetti, A. Chem. Mater. 2011, 23, 733-758. doi:10.1021/cm102419z

25. Schulze, K.; Uhrich, C.; Schüppel, R.; Leo, K.; Pfeiffer, M.; Brier, E.; Reinold, E.; Bäuerle, P. Adv. Mater. 2006, 18, 2872-2875. doi:10.1002/adma.200600658

26. Noma, N.; Tsuzuki, T.; Shirota, Y. Adv. Mater. 1995, 7, 647-648. doi:10.1002/adma.19950070709

27. Hughes, G.; Bryce, M. R. J. Mater. Chem. 2005, 15, 94-107. doi:10.1039/B413249C

28. Kulkarni, A. P.; Tonzola, C. J.; Babel, A.; Jenekhe, S. A. Chem. Mater. 2004, 16, 4556-4573. doi:10.1021/cm049473। 
29. Wu, W.; Liu, Y.; Zhu, D. Chem. Soc. Rev. 2010, 39, 1489-1502. doi:10.1039/B813123F

30. Yamada, H.; Okujima, T.; Ono, N. Chem. Commun. 2008, 2957-2974. doi:10.1039/B719964C

31. Yamao, T.; Shimizu, Y.; Terasaki, K.; Hotta, S. Adv. Mater. 2008, 20 , 4109-4112. doi:10.1002/adma.200800942

32. Masui, K.; Mori, A.; Okano, K.; Takamura, K.; Kinoshita, M.; Ikeda, T. Org. Lett. 2004, 6, 2011-2014. doi:10.1021/ol049386z

33. Campbell, N. L.; Duffy, W. L.; Thomas, G. I.; Wild, J. H.; Kelly, S. M.; Bartle, K.; O'Neill, M.; Minter, V.; Tufn, R. P. J. Mater. Chem. 2002, 12, 2706-2721. doi:10.1039/B202073B

34. Kitamura, T.; Lee, C. H.; Taniguchi, Y.; Fujiwara, Y.; Sano, Y.; Matsumoto, M. Mol. Cryst. Liq. Cryst. 1997, 293, 239-245. doi:10.1080/10587259708042774

35. James, D. K.; Tour, J. M. Molecular Wires. Molecular Wires and Electronics; Topics in Current Chemistry, Vol. 257; Springer: Berlin, Germany, 2005; pp 33-62. doi:10.1007/b136066

36. Robertson, N.; McGowan, C. A. Chem. Soc. Rev. 2003, 32, 96-103. doi:10.1039/B206919A

37. Metzger, R. M. J. Mater. Chem. 2008, 18, 4364-4396. doi:10.1039/B802804B

38. Forrest, S. R. Nature 2004, 428, 911-918. doi:10.1038/nature02498

39. Carroll, R. L.; Gorman, C. B. Angew. Chem., Int. Ed. 2002, 41 , 4379-4400. doi:10.1002/1521-3773(20021202)41:23<4378::AID-ANIE4378>3.0.CO ;2-A

40. Tour, J. M. Acc. Chem. Res. 2000, 33, 791-804. doi:10.1021/ar0000612

41. Okada, K.; Imakura, T.; Oda, M.; Murai, H.; Baumgarten, M. J. Am. Chem. Soc. 1996, 118, 3047-3048. doi:10.1021/ja9539352

42. Duesing, R.; Tapolski, G.; Meyer, T. J. J. Am. Chem. Soc. 1990, 112, 5378-5379. doi:10.1021/ja00169a071

43. Jones, W. E., Jr.; Chen, P.; Meyer, T. J. J. Am. Chem. Soc. 1992, 114, 387-388. doi:10.1021/ja00027a073

44. Daub, J.; Engl, R.; Kurzawa, J.; Miller, S. E.; Schneider, S.; Stockmann, A.; Wasielewski, M. R. J. Phys. Chem. A 2001, 105, 5655-5665. doi:10.1021/jp0037293

45. Sailer, M.; Franz, A. W.; Müller, T. J. J. Chem. - Eur. J. 2008, 14, 2602-2614. doi:10.1002/chem.200701341

46. Memminger, K.; Oeser, T.; Müller, T. J. J. Org. Lett. 2008, 10, 2797-2800. doi:10.1021/ol800920d

47. Franz, A. W.; Popa, L. N.; Rominger, F.; Müller, T. J. J. Org. Biomol. Chem. 2009, 7, 469-475. doi:10.1039/B814850C

48. Hauck, M.; Turdean, R.; Memminger, K.; Schönhaber, J.; Rominger, F.; Müller, T. J. J. J. Org. Chem. 2010, 75, 8591-8603. doi:10.1021/jo101997t

49. Jahnke, A. C.; Spulber, M.; Neuburger, M.; Palivan, C. G.; Wenger, O. S. Chem. Commun. 2014, 50, 10883-10886. doi:10.1039/C4CC03806A

50. Franz, A. W.; Popa, L. N.; Müller, T. J. J. Tetrahedron Lett. 2008, 49, 3300-3303. doi:10.1016/j.tetlet.2008.03.071

51. Sailer, M.; Nonnenmacher, M.; Oeser, T.; Müller, T. J. J. Eur. J. Org. Chem. 2006, 423-435. doi:10.1002/ejoc.200500539

52. Sailer, M.; Rominger, F.; Müller, T. J. J. J. Organomet. Chem. 2006, 691, 299-308. doi:10.1016/j.jorganchem.2005.08.012

53. Krämer, C. S.; Müller, T. J. J. Eur. J. Org. Chem. 2003, 3534-3548 doi:10.1002/ejoc.200300250

54. Krämer, C. S.; Zeitler, K.; Müller, T. J. J. Org. Lett. 2000, 2, 3723-3726. doi:10.1021/ol0066328
55. Müller, T. J. J. Tetrahedron Lett. 1999, 40, 6563-6566. doi:10.1016/S0040-4039(99)01402-1

56. Zhou, G.; Pschirer, N.; Schöneboom, J. C.; Eickemeyer, F.; Baumgarten, M.; Müllen, K. Chem. Mater. 2008, 20, 1808-1815. doi:10.1021/cm703459p

57. Hauck, M.; Stolte, M.; Schönhaber, J.; Kuball, H.-G.; Müller, T. J. J. Chem. - Eur. J. 2011, 17, 9984-9998. doi:10.1002/chem.201100592

58. Hauck, M.; Schönhaber, J.; Zucchero, A. J.; Hardcastle, K. I.; Müller, T. J. J.; Bunz, U. H. F. J. Org. Chem. 2007, 72, 6714-6725. doi:10.1021/jo070922।

59. Bucci, N.; Müller, T. J. J. Tetrahedron Lett. 2006, 47, 8329-8332. doi:10.1016/j.tetlet.2006.09.075

60. Bucci, N.; Müller, T. J. J. Tetrahedron Lett. 2006, 47, 8323-8327. doi:10.1016/j.tetlet.2006.09.076

61. Bay, S.; Villnow, T.; Ryseck, G.; Rai-Constapel, V.; Gilch, P.; Müller, T. J. J. ChemPlusChem 2013, 78, 137-141. doi:10.1002/cplu.201200279

62. Bay, S.; Makhloufi, G.; Janiak, C.; Müller, T. J. J. Beilstein J. Org. Chem. 2014, 10, 1006-1016. doi:10.3762/bjoc.10.100

63. Bay, S.; Müller, T. J. J. Z. Naturforsch., B: J. Chem. Sci. 2014, 69, 541-553. doi:10.5560/ZNB.2014-4060

64. Müller, T. J. J.; Franz, A. W.; Barkschat (née Krämer), C. S.; Sailer, M.; Meerholz, K.; Müller, D.; Colsmann, A.; Lemmer, U. Macromol. Symp. 2010, 287, 1-7. doi:10.1002/masy.201050101

65. Zhou, Z.; Franz, A. W.; Hartmann, M.; Seifert, A.; Müller, T. J. J.; Thiel, W. R. Chem. Mater. 2008, 20, 4986-4992. doi:10.1021/cm800804t

66. Meyer, T.; Ogermann, D.; Pankrath, A.; Kleinermanns, K.; Müller, T. J. J. J. Org. Chem. 2012, 77, 3704-3715. doi:10.1021/jo202608w

67. Tian, H.; Yang, X.; Chen, R.; Pan, Y.; Li, L.; Hagfeldt, A.; Sun, L. Chem. Commun. 2007, 3741-3743. doi:10.1039/B707485A

68. Park, S. S.; Won, Y. S.; Choi, Y. C.; Kim, J. H. Energy Fuels 2009, 23 , 3732-3736. doi:10.1021/ef900207y

69. Lambert, C.; Kriegisch, V. Langmuir 2006, 22, 8807-8812. doi:10.1021/la061404t

70. Barkschat, C. S.; Stoycheva, S.; Himmelhaus, M.; Müller, T. J. J. Chem. Mater. 2010, 22, 52-63. doi:10.1021/cm901514t

71. Franz, A. W.; Stoycheva, S.; Himmelhaus, M.; Müller, T. J. J. Beilstein J. Org. Chem. 2010, 6, No. 72. doi:10.3762/bjoc.6.72

72. Rechmann, J.; Sarfraz, A.; Götzinger, A. C.; Dirksen, E.; Müller, T. J. J.; Erbe, A. Langmuir 2015, 31, 7306-7316. doi:10.1021/acs.langmuir.5b01370

73. Levi, L.; Müller, T. J. J. Chem. Soc. Rev. 2016, 45, 2825-2846. doi:10.1039/C5CS00805K

74. Merkul, E.; Urselmann, D.; Müller, T. J. J. Eur. J. Org. Chem. 2011, 238-242. doi:10.1002/ejoc.201001472

75. Urselmann, D.; Antovic, D.; Müller, T. J. J. Beilstein J. Org. Chem. 2011, 7, 1499-1503. doi:10.3762/bjoc.7.174

76. Klukas, F.; Perkampus, J.; Urselmann, D.; Müller, T. J. J. Synthesis 2014, 3415-3422. doi:10.1055/s-0034-1379074

77. Klukas, F.; Grunwald, A.; Menschel, F.; Müller, T. J. J. Beilstein J. Org. Chem. 2014, 10, 672-679. doi:10.3762/bjoc.10.60

78. Franz, A. W.; Müller, T. J. J. Synthesis 2008, 1121-1125. doi:10.1055/s-2008-1032118

79. Yang, L.; Feng, J.-K.; Ren, A.-M. J. Org. Chem. 2005, 70, 5987-5996. doi:10.1021/jo050665p

80. Gaussian 09, Revision A.02; Gaussian, Inc.: Wallingford, CT, U.S.A., 2009. 
81. Yanai, T.; Tew, D. P.; Handy, N. C. Chem. Phys. Lett. 2004, 393, 51-57. doi:10.1016/j.cplett.2004.06.011

82. Scalmani, G.; Frisch, M. J. J. Chem. Phys. 2010, 132, 114110. doi:10.1063/1.3359469

\section{License and Terms}

This is an Open Access article under the terms of the Creative Commons Attribution License

(http://creativecommons.org/licenses/by/4.0), which permits unrestricted use, distribution, and reproduction in any medium, provided the original work is properly cited.

The license is subject to the Beilstein Journal of Organic Chemistry terms and conditions:

(http://www.beilstein-journals.org/bjoc)

The definitive version of this article is the electronic one which can be found at:

doi:10.3762/bjoc. 12.194 